\title{
MENUJU DIALOG ISLAM - KRISTEN: Perjumpaan Gereja Ortodoks Syria dengan Islam
}

\author{
Zaenul Arifin \\ IAIN Walisongo Semarang \\ e-mail: zaenul_arifin@yahoo.com
}

\begin{abstract}
Conflict between Christianity and Islam prevailed the pages of the history of religion. Having a common origin, the two religions always stuck in a violent conflict. This article try to explore deeply the Syrian Orthodox Church, and find out the common roots with Islam. It is found the parallelization in any theological aspect of Christianity and Islam, especially in the observance of religious duties. The data cought will have an importance in developing the dialog between Islam and Christian.

$* * *$

Konflik antara Kristen dengan Islam tampil dalam sejarah agama. Karena memiliki sumber asal yang sama, kedua agama selalu terlibat dalam kontak kekerasan. Tulisan ini mencoba untuk mengkaji secara mendalam geraja orthodoks Syria dan ditemukan akan adanya akar yang sama dengan Islam. Ditemukan pula adanya paralelisasi dalam aspek teologinya, khususnya pelaksanaan kewajiban agama. Data yang didapatkan menunjukkan arti penting dalam pengembangan dialog antara Islam dengan Kristen.
\end{abstract}

Keywords: Gereja Ortodoks Syria, paralelisasi agama, tugas keagamaan, dialog 


\section{A. Pendahuluan}

Kristen dan Islam sebagai dua agama terbesar di dunia, meskipun secara teologis memiliki ciri khas yang sama, sama-sama agama rumpun Ibrahim, agama semitis yang berasal dari Timur Tengah, namun dalam sejarahnya banyak mengalami konflik, bahkan hingga saat ini. Selama ini, khususnya dalam tataran teologis, antara Islam dan Kristen ada tembok pemisah yang dibatasi oleh paradigma dan religious language (bahasa agama) yang berbeda. Lalu muncullah sejumlah kesalahpahaman,- - plus faktor-faktor non teologis yang "memboncengi" - , maka meruncinglah perbedaan dan meletuslah kerusuhan-kerusuhan ${ }^{1}$. Konflik kedua agama tersebut disamping dipicu oleh faktor ekonomi, politik, sosial, juga disebabkan oleh sikap eklusif di antara pemeluk kedua agama. ${ }^{2}$ Padahal Agama Kristen dan Islam dapat dikatakan agama-agama monoteis, sebab semuanya menyembah Tuhan yang sama dari kedua agama tersebut. Dalam sejarah agama-agama, kelompok agama yang satu bisa saja menyerang beberapa teolog agama tertentu, bahkan dalam satu agama sekalipun. Masing-masing kelompok ingin menunjukkan kemurnian agamanya, sementara yang lain dipandang sesat.

Soal dialog antar agama, dalam sejarah, sebenarnya bukanlah hal yang baru. Sejak awal kemunculannya, umat Islam sudah terbiasa berdialog dengan siapa saja. Di Makkah, sebelum hijrah, Rasulullah SAW dan para sahabat sudah berdialog dengan kaum musyrik Arab dan pengikut Kristen. Saat hijrah ke Habsyah, Ja'far bin Abdul Muthalib sudah berdialog dengan pengikut Kristen dan juga Raja Najasyi yang ketika itu masih memeluk agama Kristen. Di Madinah, Rasulullah SAW melayani perdebatan dengan delegasi Kristen Najran.

Meskipun sejak nabi dialog Islam Kristen sudah dilakukan dan masih terus dilakukan sampai sekarang. Namun Konflik Islam-Kristen masih sering terjadi. Mengapa ini semua bisa terjadi? Ada dua faktor penyebab utama,

1 Bambang Noorsena, Memahami Kesalahfahaman, Beberapa Tema Teologis dalam Perjumpaan Kristen-Islam, (Denpasar: Bali Jagadhita Press, 2002), h. v.

2 Lihat uraian Mahmoud M. Ayaoub, Mengurai Konflik Muslim - Kristen dalam Perspektif Islam, terj. Ali Noer Zaman, (Yogyakarta: Fajar Pustaka Baru, 2001). 
yaitu faktor eksoterik dan esoterik. ${ }^{3}$ Faktor eksoterik itu meliputi faktor sejarah (historisitas), sosial dan budaya (kultural), sedangkan faktor esoterik meliputi lima konsep atau bisa dikatakan dogma, yaitu konsep Ketuhanan (theisme), keselamatan (soteriologi), pemahaman tentang kitab suci (scriptural), klaim kebenaran (truth claims), dan pemahaman tentang agama lain (religiusitas). Dialog teologis yang dimaksudkan di sini adalah dialog yang mencakup kedua wilayah agama tersebut, yaitu eksoterik dan esoterik.

Hubungan Islam-Kristen di Indonesia, pada salah satu aspeknya mewarisi "beban sejarah" dari para pendahulunya, yaitu para pembawa kedua agama: Islam hampir identik dengan Arab (Timur Tengah) dan Kristen dengan Barat. ${ }^{4}$ Dalam kaitan ini, banyak ahli studi kekristenan Timur Tengah berpendapat bahwa Kekristenan Ortodoks Syria-lah yang paling banyak memiliki kesamaan istilah keagamaan dan titik temu dengan Islam. ${ }^{5}$

Berangkat dari kesamaan akar inilah, terletak relevansi ajaran-ajaran teologis dari Gereja Ortodoks Syria untuk dikemukakan dalam dialog IslamKristen. Untuk itu sebagai upaya menambah wacana dan tradisi dialog antara Islam dan Kristen, maka dialog teologis Islam-Kristen lewat Gereja Ortodoks Syria, yang belum banyak dikenal di Indonesia ini, baik oleh umat Islam maupun umat Kristen sendiri, layak untuk dikedepankan. ${ }^{6}$

\footnotetext{
${ }^{3}$ Eksoterik yaitu faktor-faktor dari luar yang tidak bisa dipisahkan dari agama, sehingga dikatakan juga sebagai faktor kulit agama. Esoterik yaitu faktor-faktor dari dalam yang fundamental, terutama menyangkut pengajarannya.

${ }^{4}$ Idries Sah, Meraba Gajah dalam Gelap: Sebuah Upaya Dialog Kristen-Islam, (Jakarta: Grafiti Press, 1986), h. 42.

${ }^{5}$ Arthur Jeffery, The Foreign Vocabulary of the Qur'an, Lahore: Al-Biruni, 1977, h. 19. Lihat juga: Alphonsus Mingana, "Syrian Influence on the Style of the Kur'an," Bulletin of the John Rylands Library, Manchester 11, (1927), h. 83 dan J. Spencer Trimingham, Christianity among the Arabs in Pre-Islamic Times (London: Longman Group Ltd., 1979), h. 267.

${ }^{6}$ Masuknya Gereja Ortodoks Syria di Indonesia ini diawali dari perjalanan Bambang Noorseno ke Syria. dan sempat melakukan studi agama di negara tersebut sekitar tahun 1995. Pusat Gereja Syria ini terletak di Jl. Supriyadi IX-A No. 8. Malang, Jawa Timur. Hanya, mereka belum memiliki gereja. Di Surabaya sendiri mereka masih nebeng dengan gereja lain. Sebab, membentuk gereja bagi kalangan ortodoks tidak semudah kalangan lain. Diharuskan memiliki imam yang meraka sebut dengan abuna (ayah kami). Untuk menjadi seorang abuna tiduk mudah. Harus menguasai lima bahasa: Arab, Aram, Ibrani, Yunani, dan Inggris. Namun, gereja ortodoks pimpinan Noorseno ini belum terdaftar di Departemen Agama. Lihat M.H., Titi A.S., dan Abdul Manan Surabaya, D\&R, edisi 981003-007/h. 38 Rubrik Agama, "Gereja dengan Haji dan Salat”, http://jurnalis.wordpress. com/1998/10/03/gereja-dengan-haji-dan-salat/, diakses pada tanggal 26 Nupember 2007.
} 


\section{B. Sejarah dan Perkembangan Gereja Ortodoks Syria}

Gereja Ortodoks Syria, nama resminya Idto Suryoyto Treeysath Shubho, dalam bahasa Inggris , Syriac Orthodox Church, ${ }^{7}$ - gereja ini di Barat sering disebut sebagai sebagai Jacobit ${ }^{8}$ atau Monophysit, ${ }^{9}$ tetapi julukan ini dianggap menyesatkan, para pengikut gereja ini lebih menyukai istilah Gereja non Chalcedonia $^{10}$ atau Gereja Miafisit ${ }^{11}$ _adalah salah satu gereja Kristen tertua yang berakar dari Gereja Antiochia. ${ }^{12}$

Di kota Anthiochia inilah para pengikut Yesus, untuk pertama kalinya dijuluki orang Kristen ${ }^{13}$ Selain dijuluki orang-orang Kristen (para pengikut Kristus), mereka juga dijuluki orang-orang Syria (Syrians dalam bahasa

7 Nama ini dipakai berdasarkan keputusan Sinode tahun 2000, sebelumnya nama yang dipakai dalam bahasa Inggris adalah Syrian Orthodox Church, nama ini dirubah untuk menunjukkan bahwa gereja ini tidak berkaitan dengan pemerintah Syria. Lihat Wikipedia, http:// en.wikipedia.org/ wiki/Syriac_Orthodox_Church, diakses pada tanggal 29 November 2007.

8 Nama ini diberikan oleh musuh Gereja Ortodoks Syria dengan maksud merendahkannya dan berusaha membuat opini bahwa gereja ini didirikan oleh Jacob Baradaeus. Pada abad keenam, Gereja Ortodoks Syria mengalami penyiksaan dibawah kendali Kekaisaran Byzantium yang memaksakan ajarannya. Pada situasi inilah Jacob Baradaeus tampil. Ia melakukan perjalanan ke daerah Timur dan menetapkan Imam dan Diakon untuk mencegah lenyapnya gereja ini. Jacob dianggap sebagai pahlawan iman di Gereja Ortodoks Syria, tetapi bukan pendirinya. Perlu diketahui, bahwa Kekristenan Ortodoks Syria yang di Malankara (India) tanpa pikir panjang menyebut diri mereka sebagai Jacobit. Padahal selama berabad-abad mereka disebut Nasrani. Istilah Jacobit pertama kali dikenalkan di Malankara pada abad 19 oleh jemaat Anglikan. Lihat FAQ http: //www.angelfire.com/journal2/iscs/faq.htm, diakses pada tanggal 27 Desember 2007.

${ }_{9}^{9}$ Ajaran yang dikemukakan oleh Eutyches seorang rahib dari Gereja Byzantium, yang mengajarkan bahwa keilahian Yesus sebagai firman Allah itu sedemikian rupa, sampai menenggelamkan sama sekali kemanusiaan Yesus dalam keilahian-Nya itu. Ajaran ini sangat meresahkan gereja, karena dengan menyangkal kemanusiaan Yesus dan hanya mengakui keilahian-Nya, akan berarti pula bahwa Firman Allah dapat menderita dan mati ditiang salib. Lihat Bambang Noorsena, Memahami Kesalahpahaman, Beberapa Tema Teologis dalam Perjumpaan Kristen-Islam, (Denpasar: Bali Jagadhita Press, 2002), h. 50.

10 Gereja ini menolak dogma kristologis yang dikeluarkan oleh Konsili Chalcedon (451 M.), yang enyatakan bahwa Yesus memiliki dua hakikat (Diofisit), ilahi dan insani, yang tidak terpisahkan dan hanya bertindak sebagai satu hypotasis. Lihat,"Gereja Ortodoks Oriental," Wikipedia Indonesia, http://id.wikipedia.org/wiki/Gereja-Ortodoks-Oriental, diakses pada tanggal 29 April 2007.

${ }^{11}$ Miafisitisme (terkadang disebut henofisitisme) adalah kristologi dari Gereja-Gereja Ortodoks Oriental. Menurut miafisitisme, dalam satu pribadi Yesus Kristus itu, keilahian dan kemanusiaan dipersatukan dalam satu "hakikat" ("fisis"), keduanya dipersatukan tanpa pemisahan, tanpa pembauran, dan tanpa alterasi. Lihat "Miafitisme," Wikipedia Indonesia, http://id.wikipedia.org /wiki/Miafisitisme, diakses pada tanggal 27 Desember 2007.

12 Lihat Wikipedia, http:// en.wikipedia.org/ wiki/Syriac_Orthodox_Church, diakses pada tanggal 29 November 2007.

${ }^{13}$ Al-Kitab, Perjanjian Baru, Kisah Para Rasul;11:26, Jakarta: Lembaga Al-Kitab Indonesia, 1993), h. 169. Lihat juga "History of the Syriac Orthodox Church," Syriac Orthodox Resources, http://sor.cua.edu/History/index.html, diakses pada tanggal 26 November 2007. 
Inggris). Nama ini diambil dari nama Cyrus, Raja Persia (559-529 SM.) yang menaklukkan Babylon (539 SM.) dan membebaskan orang-orang Yahudi untuk kembali ke Judea. Nama ini disebutkan oleh Nabi Isaiah, dan dihubungkan dengan Kristus. Sejak itu istilah orang-orang Syria, dipakai pertama-tama untuk orang-orang Kristen dari Syria (Suriah), dan kemudian dipakai juga untuk menyebut orang-orang Kristen dari Mesopotamia, Persia, India, dan Timur jauh, yang masuk Kristen karena para rasul dan pendeta yang berasal dari Syria.

Nama ini digunakan di Syria untuk membedakan antara orang-orang Aram Kristen dan kafir. Istilah "Aramean" sinonim dengan "Kafir," dan istilah "Syrian" sinonim dengan "Kristen". Demikian juga bahasa Aram disebut bahasa Syria (Syriac). Hingga sekarang ini orang-orang Kristen yang memakai bahasa Syria disebut "Suroye," "Suraye," "Curcaye". Sedangkan istilah "Kristen" dipakai untuk orang-orang Kristen Barat. ${ }^{14}$

Rasul15 Petrus ${ }^{16}$ dipercaya telah mendirikan sebuah gereja di Antiochia pada tahun $37 \mathrm{M},{ }^{17}$ yang sisa-sisanya sekarang terdapat di Antakya (nama

14 H. H. Moran Mor Ignatius Yacoub III, "About the Syrian Orthodox Church," Syrian Orthodox Church, http://www.syrianorthodoxchurch.net/Location/Global/SOC-index-Global-en.htm, diakses tanggal 27 November 2007.

15 Dalam Kristen istilah Rasul itu berasal dari bahasa Ibrani, Shelihah. Bentuk jamaknya Shelihim. Kisah Rasul-Rasul, bahasa Ibraninya: Miph'a lot ha-Selihim. Konteksnya sama sekali berbeda dengan istilah rasul dalam Islam. Istilah shelihah berasal dari sinagoge Yahudi, yaitu wakil dari imam (kohen) dalam memimpin ibadah. Nah, Yesus dalam iman Kristen diyakini sebagai imam besar (kohen hanggadol) menurut nubuat dalam Mazmur 110:4. Dalam konteks seperti ini, muridmurid Yesus adalah para "shelihah"Yesus sebagai Imam Besar. Dalam al-Qur'an, murid-murid Yesus dijuluki Hawariyin. Ternyata sebutan Hawari berasal dari bahasa Habshi/Ethiopia. Maknanya sama dengan shelihah tadi. Tetapi entah sebelum zaman Islam atau sesudahnya istilah rasul diterapkan bagi murid-murid Yesus dalam bahasa Arab. Lihat Bambang Noorsena, Menuju Dialog Teologis Kristen Islam, (Yogyakarta: Yayasan Andi, 2001), h.131.

16 Petrus adalah salah seorang dari dua belas murid Yesus yang merupakan orang pertama dalam gereja dan dianggap sebagai pemimpin jemaat induk di Yerusalem. Dalam Injil Matius; 16:18, disebutkan: "Dan Akupun berkata kepadamu: Engkau dalah Petrus dan dia atas batu karang ini Aku aku akan mendirikan jemaat-Ku dan alam maut tidak akan menguasainya". Bahkan Yesus mengangkat Petrus sebagai kepala gereja yang tertinggi, sebagaimana diisyaratkan dalam Injil Yohannes; 21:17. Pada awal mulanya jemaat Kristen terdiri dari orang-orang Yahudi. Merekalah yang disebut dengan jamaat purba atau jemaat Yerussalem, atau ada pula yang menyebut mereka dengan jemaat Nazaret. Agama Kristen pada mulanya adalah untuk bangsa Yahudi, suatu agama nasional bangsa Yahudi. Akan tetapi, ketika Petrus bekerja di Yerussalem, sudah terdapat petunjuk bahwa dia membaptis seorang warga Roma, bernama Kornelius, bersama keluarganya di Kaesaria, dekat Yerussalem. Ini berarti bahwa agama Kristen berubah dari agama nasional bangsa Yahudi menjadi agama yang bersifat internasional. Hal inilah yang merupakan permasalahan bagi gereja Yerussalem sehingga Petrus menghadapi perlawananan. Pada tahun $42 \mathrm{M}$, ia pindah ke Roma secara misterius, dan menjadi paus yang pertama di sana. Petrus menjabat sebagai paus selama 25 tahun 
moderen dari Antiochia), Turki. Kelanjutan dari gereja inilah yang sekarang disebut Gereja Ortodoks Syria.

Gereja Antiochia memainkan suatu peran yang penting pada awal sejarah Kekristenan. ${ }^{18}$ Mereka memainkan peranan dalam tiga konsili yang pertama, yaitu konsili pada Nicea (325.), Constantinople (381 M.), dan Ephesus (431 M), yang merumuskan doktrin Kristen awal. Setelah konsili Chalcedon (451 M. ), gereja Anthiochia terpecah menjadi dua, yang menerima hasil dari konsili Chalchedon disebut Gereja Ortodoks Timur Anthiochia dan yang menolak dikenal sebagai 'Idto SuryoytoTreeysath Shubho (Gereja Ortodoks Syria) ${ }^{19}$.

Bersama dengan Gereja Alexandria (Koptik), kedua gereja yang menolak konsili Chalcedon ini, kemudian disebut Gereja Ortodoks Oriental. ${ }^{20}$ Selain

dan meninggal dunia pada 67 M. Lihat Fathudin Abdul Gani, "Agama Katolik," dalam Djam'annuri (ed), Agama-agama di Dunia, (Yogyakarta: IAIN Sunan Kalijaga Press,1988), h. 341. Nama asli Petrus adalah Simon: yang diberi nama Petrus (Bahasa Yunani: petros, petra; Bahasa Aram: kēf; Bahasa Inggris: rock; Bahasa Indonesia: Batu Karang) oleh Yesus, dikenal pula dengan sebutan Simon bar Yonah atau Simon bar Yokhanan (Bahasa Aram), dan sebelum itu disebut dengan nama (Surat-Surat Paulus lebih dahulu ditulis) Kefas (Bahasa Aram) oleh Paulus dari Tarsus, dan Simon Petrus, nelayan dari Betsaida “di Galilea” (Yohanes 1:44; bdk. 12:21) Lihat, 'Keduabelas Rasul', Wikipedia Indonesia, ensiklopedia bebas berbahasa Indonesia, "http://id.wikipedia.org/wiki/Keduabelas_Rasul, diakses tanggal 2 Januari 2008.

${ }^{17}$ Sumber lain menyatakan tahun 34 M., lihat "Syriac Orthodox Church,"loc. cit.

18 Pada abad ke-4, Uskup Antiochia menjadi uskup yang paling senior di kawasan yang sekarang meliputi Turki Timur, Libanon, Israil, Palestina, Syria, Yordania, Iraq dan Iran. Jajarannya melayani jumlah tebesar orang Kristen di dunia pada saat itu. Lihat, "Patriarch of Antioch," Wikipedia, the free encyclopedia, "http://en.wikipedia.org/wiki/ Patriarch_of_Antioch, diakses pada tanggal 3 September 2009.

19 "History of the Syriac Orthodox Church," loc. cit.

${ }^{20}$ Istilah Ortodoks ini muncul pada masa awal gereja, bersamaan dengan, munculnya aliran "gnostikisme," yaitu suatu bid'ah Kristen yang mengubah iman Kristen menjadi semacam ajaran kebatinan. Dalam melawan ajaran bid'ah gnostik inilah Gereja yang Rasuliah itu menyebut ajaran asli yang rasuliah itu sebagai ajaran ("doxa") yang "lurus" ("orthos"), Ortho + doxa = Orthodox. Sedangkan ajaran "gnostik" itu sebagai ajaran ("doxa") yang berbeda atau menyimpang ("heteros"), hetero + doxa = Heterodox, lihat, "Sejarah Gereja Orthodox," Gereja Orthodox Indonesia, http://www.goina.org/?uPos= L\&uMenu=10\&uSys=19\&uCaption=Sejarah\%20Gereja, diakses pada tanggal 27 Desember 2007. Sekarang ini yang termasuk komuni Ortodoks Oriental adalah; Gereja Apostolik Armenia, Gereja Ortodoks Koptik di Alexandria yang meliputi: Gereja Tewahedo Ortodoks Ethiopia, dan Gereja Tewahedo Ortodoks Eritrea, Gereja Ortodoks Britania, Gereja Timur Ortodoks India, dan Gereja Ortodoks Syria, yang meliputi juga Gereja Ortodoks Syria Yakobit Malankara, lihat "Gereja Ortodoks Oriental," loc. cit.. Sedangkan Gereja Ortodoks Yunani yang pecah dengan Katolik Roma pada tahun 1054, biasa disebut Eastern Orthodox (Eastern, menunjuk Roma Timur, yaitu Yunani/Konstantinopel sebagai lawan dari Western, Roma Barat/Latin). Karena itu dalam bahasa Arab, Gereja Ortodoks Yunani disebut juga gereja Rumi Ortodoks, untuk membedakan dengan Rumi Kathuliq. Sedangkan Gereja Ortodoks Syria dan Koptik, lazim disebut Oriental Orthodox 
karena penolakan terhadap keputusan konsili Chalcedon, sebab lain yang mejadikan perpecahan dalam gereja di Timur ini adalah kesadaran kebangsaan yang melawan kuasa pusat kekaisaran. ${ }^{21}$

Akibat dari perpecahan ini menjadikan Gereja Ortodoks Syria menjadi gereja yang paling teraniaya oleh sesama Kristen. Mereka menjadi sasaran fitnah dan dicap sebagai aliran heresy (sesat) bahkan penganiayaan fisik oleh pihak Byzantium, sampai-justru tentara Arab Muslimlah-yang membebaskan mereka. ${ }^{22}$

Kepala Gereja Ortodoks Syria sekarang ini adalah Patriach Ignatius Zakka I Iwas. Gereja ini terdiri dari 26 archdiosis (keuskupan agung) dan 11 patriachal vicarat. Patriach Zakka ditahbiskan sebagai kepala gereja pada tanggal 14 September 1980 M. ${ }^{23}$ Patriach Ortodoks Syria biasanya dikenal dengan namanya sendiri, tetapi sejak tahun 1293 M., Patriach Antiochia memakai nama Ignatius, dan berlanjut sampai sekarang. Dimana Ignatius Zakka I menjadi patriach yang ke 122.24 Kantor Patriachat sekarang ini berada di Bab Touma, Damaskus, ibu kota Syria; tetapi patriach bertempat tinggal di Biara Mor Aphrem di Ma'arat Sayyidnaya, yang berlokasi kurang lebih $25 \mathrm{~km}$ sebelah utara Damaskus ${ }^{25}$

Pemimpin tertinggi dari Gereja Ortodoks Syria adalah "Patriach Antiochia dan seluruh daerah Timur," ia juga memimpin Synod Suci, majelis dari seluruh uskup. Pemimpin lokal dari gereja di Malankara India adalah "Katolikos dari India" Basilius Thomas I, berada di bawah yurisdiksi dari Patriach Antiochia dan bertanggung jawab pada Synod Suci, dan synod lokal Malankara. Dia ditahbiskan oleh patriach, dan memimpin Synod Suci lokal.

Pemimpin dari setiap Keuskupan Agung adalah seorang Uskup Agung, yang berada di bawah yurisdiksi dari patriach dan bertanggung jawab pada

(Ortodoks budaya Timur Tengah). Lihat Bambang Noorsena, Menuju Dialog Teologis Kristen Islam, h. 147.

${ }^{21}$ I. H.Enklaar, Sedjarah Gereja Ringkas, (Jakarta: Badan Penerbit Kristen, 1955), h. 29.

22 Bambang Noorsena, Menuju Dialog Teologis Kristen Islam..., h. 42.

23 Lihat Wikipedia, http:// en.wikipedia.org/ wiki/Syriac_Orthodox_Church, diakses pada tanggal 29 November 2007.

24 "The Syriac Orthodox Church, A Brief Overview," http://sor.cua.edu/Intro/ index.html, diakses pada tanggal 22 Desember 2007, lihat juga 'Syriac Orthodox Church', loc. cit.

25 Lihat Wikipedia, http:// en.wikipedia.org/ wiki/Syriac_Orthodox_Church, diakses pada tanggal 29 November 2007. 
Synod Suci, ia juga ditahbiskan oleh patriach dan paling sedikit dua orang uskup.

Setiap kepastoran diangkat seorang imam yang berada di bawah yuridiksi uskup agung dan langsung bertanggungjawab kepadanya. Kepastoran dijalankan oleh sebuah komite yang dipilih oleh jamaah kepastoran dan dikukuhkan oleh uskup agung. Deacon membantu imam dalam administrasi peribadahan, setiap keuskupan agung biasanya mempunyai seorang deacon agung yang dijuluki "tangan kanan dari uskup".

Di Gereja Ortodoks Syria terdapat tiga tingkatan kependetaan, yaitu: Episcopate (uskup), meliputi tingkatan patriach, chatolicos, uskup agung, dan uskup. Vicarate (imam), meliputi sub-uskup dan pastor. Deaconate (deacon), meliputi deacon agung, evangelical-deacon, sub-deacon, lektor atau qoruyo dan penyanyi atau mzamrono. ${ }^{26}$

Pengikut dari Gereja Ortodoks Syria ini di seluruh dunia diperkirakan berjumlah sekitar 2.250 .000 orang, termasuk 1.200 .000 orang di India, dengan memasukkan pengikut dari Gereja Ortodoks India. Gereja Ortodoks India ini kadang-kadang disalahpahami sebagai bagian dari Gereja Ortodoks Syria, walaupun mereka berasal dari satu tradisi dan suatu saat berwadah tunggal, mereka terpecah dalam dua bentuk yang independen. Satu otonomi di bawah Gereja Ortodoks Syria, dan yang lain Gereja India Ortodoks yang authocephalous. ${ }^{27}$

Setelah berkurang akibat invasi Mongol pada abad ke-14, perpecahan pada abad ke-18 dengan berdirinya Gereja Katolik Syria, akibat pembantain yang dilakukan penguasa Turki, serta emigrasi sejumlah besar pengikutnya ke Eropa Barat pada tahun 1960-an. ${ }^{28}$ Sekarang ini di Syria terdapat 680.000 orang pengikut, dan di Turki berjumlah 5.000 orang. Sedangkan di Jerman

\footnotetext{
${ }^{26}$ St. Thomas Syriac Orthodox Church, http://stsyriacchurch.homeip.net/history. htm, diakses pada tanggal 27 November 2007.

27 Berdiri sendiri dengan satu kepala atau pemimpin.Lihat "Denominasi" Kristen Wikipedia Indonesia, ensiklopedia bebas berbahasa Indonesia, http://id.wikipedia.org.wiki. Denominasi_Kristen, diakses pada tanggal 7 Mei 2007.

${ }^{28}$ E. A. Livingstone. "Syrian Orthodox Church." The Concise Oxford Dictionary of the Christian Church. 2000. Encyclopedia.com. http://www.encyclopedia.com/doc/1095-SyrianOrthodoxChurch.html, diakses pada tanggal 10 Juni 2009.
} 
70.000 orang, di Swedia 60.000, di Belanda 15.000, dan sejumlah besar pengikut di Amerika Utara dan Selatan serta Australia. ${ }^{29}$

Di Indonesia pengikut gereja ini memang belum cukup banyak, baru sekitar 100 orang. Tapi kalau simpatisan, sudah mencapai ribuan. Untuk menjadi pengikut resmi di Indonesia belum bisa dilakukan, karena Gereja Ortodoks Syria di Indonesia belum mempunyai imam dan gereja. Padahal untuk bisa menjadi pengikut resmi harus melewati prosedur pembaptisan seorang imam. Di Indonesia, gerakan dari para pengikut gereja ini baru bersifat studi atau kajian, yang dipelopori oleh Bambang Noorsena sejak tahun 1997. Sebab itu, untuk sementara ini bagi jamaah yang ingin menjadi pengikut resmi gereja ini (di Indonesia dinamakan Kanisah Ortodoks Syria) harus melalui prosedur pembaptisan Abuna Abraham Oo Men di Singapura ${ }^{30}$

\section{Parelelisasi Gereja Ortodoks Syria dan Islam}

\section{Aspek Bahasa Teologis}

Gereja Ortodoks Syria (Antiochia) bersama dengan Gereja Alexandria (Koptik) menolak rumusan yang dihasilkan oleh Konsili Chalcedon-yang diterima oleh Gereja Barat, Roma dan Konstantinopel-yang menyatakan kesatuan pribadi Yesus "dalam dua kodrat". Selengkapnya sebagai berikut: "sesungguhnya kami bersama-sama dengan sepakat memahami, bahwa Putra Yang Tunggal, yang tidak lain yaitu Gusti kita Isa al-Masih, adalah sempurna dalam keilahian (sebagai Firman Allah) dan sempurna dalam ke-

29 'Lihat Wikipedia, http:// en.wikipedia.org/ wiki/Syriac_Orthodox_Church, diakses pada tanggal 29 November 2007. Sumber lain menyebutkan jumlah para pengikut Gereja Ortodoks Syria ini di Timur Tengah adalah 670.000 orang, dengan rincian di Syiria; 600.000, Turki; 5.000, Yordania; 50.000, Iraq; 12.000, Libanon; 2.000 dan Mesir;1.000 orang, sedang di negara-negara lain 2.400 .000 orang. Lihat Tore Kjeilen, "Syrian Orthodox Church," Encyclopediae of The Orient, http://i.cios.com/ e.o/syr. orth.htm., diakses tanggal 27 Desember 2007.

30 Lambertus L. Hurek, Gereja Ortodoks Syiria di Indonesia, http://hurek.blogspot. com/2005/12/gereja.ortodoks.syria.di.Indonesia.html., diakses pada tanggal 27 Desember 2007. Meskipun terdapat berita yang menyatakan bahwa gereja ini telah mengabarkan Injil pada abad ketujuh di Indonesia: di Pancur dan Barus, Sumatra, bahkan ada berita bahwa mereka juga ada di Kerajaan Majapahit.Lihat Gereja Orthodox Indonesia, loc. cit. Demikian juga Abu Salih al-Armini dalam bukunya, Tadhakkur fiha Akhbar min 'l-Kanais wa 'l-Adyar min nawahin Mishri wa 'l-Iqtha'aih, memuat informasi mengenai masuknya Injil pertama kali yang dibawa oleh orang Syria ke Nusantara, yaitu deskripsinya kota Fansur, Sumatra Barat. Dikisahkan disana sudah banyak Gereja dan orang Kristen di sana berasal dari Syria Timur/Nestorian. Lihat Bambang Noorsena, Menuju Dialog Teologis Kristen Islam, h. 100-101. 
manusiaan, benar-benar ilahi dan benar-benar insani, mempunyai jiwa akali dan tubuh, sehakikat dalam dzat dengan Bapa dalam kodrat Ilahi-Nya, dan sehakikat dalam dzat dengan kita dalam kodrat insani-Nya, dalam segala hal sama dengan kita kecuali dalam hal berbuat dosa, dilahirkan dari Allah sebelum segala abad dalam kodrat Ilahi-Nya sebagai Firman Allah, dan dilahirkan demi kita dan demi keselamatan kita, dalam kodrat insani-Nya dalam zaman akhir ini dari Perawan Maria, Bunda (Firman) Allah. Sesungguhnya hanya ada satu-satunya al-Masih, yang tidak lain adalah Sang Putra, Gusti, Putra Allah yang tunggal dalam dua kodrat, tidak berbaur, tidak berubah, tidak terbagi dan tidak terpisah. Karena kesatuan-Nya tidak menghilangkan kedua kodratnya, tetapi sifat-sifat kedua kodrat itu tetap terpelihara, yang pada akhirnya menjadi satu pribadi dan satu zat, dimana kodrat itu tidak tercerai dan tidak terbagi menjadi dua pribadi, tetapi hanya ada satu Putra yang tunggal, yang tidak lain adalah Firman Allah dan Gusti kita Isa al-Masih." 31

Kedua gereja tersebut mengikuti satu ajaran Kyrilos dari Alexandria, bahwa Yesus mempunyai "satu kodrat ganda," yaitu satu kodrat Firman Allah yang menjadi manusia. Sebagaimana kesalahfahaman Gereja Barat atas kristologi non Chalcedonia, demikian pula Theodoretus dari Cyrus pernah menuduh seolah-olah dengan penekanannya atas ajaran Firman Allah yang menjdi manusia itu, Kyrillos mengajarkan seolah-olah Allah dapat menderita. Padahal Kyrillos menekankan bahwa penderitaan itu dialami al-Masih "dalam tubuh kemanusian-Nya" (Petrus I, 3: 18), bukan dalam kodrat Keilahian-Nya sebagai firman yang tidak dapat menderita dan tidak dapat mati.

Gereja Ortodoks Syria juga tidak menerima hasil Konsili Konstantinopel III (680-681 M) yang melahirkan ajaran monoteletisme, yang menyatakan Yesus hanya mempunyai kehendak tunggal. Padahal tanpa kehendak manusia Yesus tidak mungkin menjadi manusia sejati, dan tidak dapat dikatakan bahwa Ia "sama dengan kita, Ia telah dicobai" (Ibrani 4:15). ${ }^{32}$

Demikian juga keputusan Konsili Toledo (568), yang menambahkan filiouque $^{33}$ dalam: Qanūn al-Imān, bahwa Ruh Kudus keluar dari Bapa dan Putra, ditolak oleh gereja ini. ${ }^{34}$

\footnotetext{
${ }^{31}$ Bambang Noorsena, Memahami Kesalahfahaman, Beberapa Tema Teologis ...., h. 52-53.

32 Ibid., h. 58-59.

${ }^{33}$ Klausa Filioque (filioque artinya "dan [dari] putra" dalam Bahasa Latin), adalah klausa penuh perdebatan yang ditambahkan ke dalam Kredo Nicea, yang menjadi perbedaan divisif khususnya
} 
Dalam menjelaskan ajaran Trinitas, gereja-gereja ortodoks di Timur mempertahankan bahwa sumber keilahian hanya satu, yaitu wujud Allah (dikiaskan Bapa); Wa an lā ilāha ilallāh al-Ahad....wa huw al-Abu lladzi minhu kullu shai'in. Sesungguhnya tidak ada ilah kecuali Allah, Yang Maha Esa, yaitu Bapa yang dari pada-Nya berasal segala sesuatu (Kor. I,:4-6, teks bahasa Arab). Dari satu Esensi kekal inilah, Firman Allah keluar sebelum segala zaman (Divine Birth of the Son, Injil Yoh.1:1-3) dan bersamaan dengan itu Hayat/Ruh Allah juga berasal;"...yaitu Ruh Kebenaran yang keluar dari Bapa" (Yohanes 15:26, teks Arab: Rūḥ al Haqq al-munbashiqu min 'l-Ab). ${ }^{35}$

Dengan demikian, Gereja-gereja Timur menegaskan bahwa Ruh Allah itu (seperti juga Firman-Nya) sama-sama keluar dari Allah, dan bukan Ruh Allah keluar dari wujud-Nya (Bapa) dan Firman-Nya (putra), yang dalam pandangan Gereja-gereja Timur dianggap mencederai keesaan-Nya. Untuk menegaskan kesatuan yang mendalam antara karya keselamatan al-Masih dengan Ruh Kudus, Gereja-gereja Timur bisa saja menerima rumusan bahwa Ruh Allah itu keluar dari Allah sebagai satu-satunya esensi Ilahi, tetapi penerimaan Ruh Allah itu ke dunia melalui Putra, yaitu sosok nuzul Firman sebagai manusia dalam karya-Nya sebagai Mesiah. ${ }^{36}$

Berkaitan dengan hal ini, Mar Philoxenos al-Manjub (w. 485), salah seorang dari bapa Gereja Ortodoks Syria, mengubah nyanyian Natal: “Ia yang dilahirkan dari Bapa secara ilahi tanpa jasad, adalah juga yang dilahirkan dari Perawan Maryam secara jasadi tanpa bapa. Ia yang satu berasal dari dua, Ilahi sekaligus insani" ${ }^{37}$

antara Gereja Katolik Roma dan Gereja Ortodoks Timur. Klausa ini disisipkan dalam naskah asli Kredo Nicea yang berbunyi "Kami percaya akan Roh Kudus ... yang keluar dari Sang Bapa”, sehingga versi yang telah diberi sisipan tersebut kini berbunyi "Kami percaya akan Roh Kudus ... yang keluar dari Sang Bapa dan Sang Putra". Penambahan ini diterima oleh umat Kristiani Katolik Romawi namun ditolak oleh umat Kristiani Ortodoks Timur. Banyak Gereja Katolik Timur tidak menggunakan klausa tersebut dalam kredo mereka, namun mengakui dokrin yang terepresentasi di dalamnya, karena klausa ini adalah dogma dalam iman Katolik Romawi. Sejauh ini Gereja Protestan juga menerimanya. Klausa ini lebih sering disebut "filioque”. Lihat Wikipedia Indonesia, ensiklopedia bebas berbahasa Indonesia, Filoque, http://id.wikipedia.org/ wiki/Filioque, diakses tanggal 2 Januari 2008.

${ }^{34}$ Bambang Noorsena, Menuju Dialog Teologis Kristen Islam, h. 20.

35 Ibid., h. 21.

36 Gelar untuk Yesus yang berasal dari bahasa Ibrani, Mesias, dalam bhs Yunani diterjemahkan, Khristhos, bahasa Arab, al-Masih, yang berarti: "yang telah diurapi". Maksud gelar ini yaitu Yesus telah diurapi Allah menjadi Juru Selamat Dunia. Lihat, Nico Syukur Dister, Kristologi, Sebuah Sketsa, (Yogyakarta: Kanisius, 1993), h. 24.

${ }^{37}$ Bambang Noorsena, Memahami Kesalahfahaman, Beberapa Tema Teologis ..., h. 76. 
Dalam makna inilah Ruh Allah itu juga disebut Ruh Yesus (Kisah 15:7; Filipi1:19). Maksudnya bukan Ruh yang keluar dari Yesus, melainkan Ruh yang diutus Bapa demi nama Mesiah, "tetapi Penghibur, yaitu Ruh Kudus, yang diutus oleh Bapa demi Nama-ku" (Yohanes 14:26). ${ }^{38}$

Dalam Kristen ortodoks, ditegaskan: Akal Ilahi (Firman Allah) berdiam dalam Dzat Ilahi sejak azali. Tidak pernah ada sekejappun dalam suatu waktu, di mana Dzat Ilahi itu ada tanpa 'aql atau pikiran-Nya, karena itu 'aql atau pikiran-Nya tersebut berada dalam Allah tanpa pemisahan dengan-Nya, sebab Allah itu tidak terbagi-bagi. ${ }^{39}$

Para teolog Kristen berbahasa Arab sering menerjemahkan padanan istilah Bapa dan Putra dan Ruh Kudus sebagai: al-wujud, al-ilmu dan al-hayat (istilah-istilah yang juga sering dipakai dalam Ilmu Kalam). Dengan demikian, berbicara tentang 'Ilm al-Qadim (The Divine Logos) dan Hayat al-Qadim (The Divine Life) dalam Wujūd al-Qadìm (The Divine Subtance), tanpa mengakibatkan ta'addud al-qudam $\bar{a}^{\prime}$ (terbilangnya Yang Qadim), sebenarnya hanya menegaskan aspek-aspek dalam keesaan Allah itu sendiri.40

Fakta ini menurut Bambang yang diakui oleh Taib Thahir Abdul M'uin ${ }^{41}$ yang menggolongkan pandangan di atas dalam mazhab wahdah (mengakui keesaan Allah). ${ }^{42}$

Selanjutnya dalam literatur Arab istilah Allah (lebih khusus dibandingkan dengan istilah-istilah padanannya: Elohim, Theos, Dieu, God), lebih menunjuk kepada Bapa itu sendiri. Karena itu dalam lingkungan Kristen Arab, tidak disebutkan: Allāh al-Mutajjasad (Allah menjadi Manusia), tetapi lebih dikenal istilah Ibnullah al-mutajjasad (Putra Allah menjadi Manusia). Maksudnya: wa kalimatuhu wa huwa nazala min 'l-samā' (yaitu Firman-Nya yang

38 Ibid., h. 29.

${ }^{39}$ Anba Yuanis, 'Aqidat al-Masihiyyin fi ' I- Masih, (Kairo: Mathraniyyat al-Aqbaath Al-Orthododoks bi Al-Ghurubiyyah, 1980), h. 34-35, dalam Bambang Noorsena, ibid,, h. 16.

40 Bambang Noorsena, Menuju Dialog Teologis Kristen Islam, h. 23.

${ }^{41}$ Lihat Taib Thahir Abdul Mu'in, Ilmu Kalam, (Jakarta: Widjaya, 1986), h. 54-55.

42 Ibid., h. 23, hanya saja menurut Bambang, ada kesalahan identifikasi mazhab-mazhab Kristen di Timur Tengah, mazhab yang digolongkan Wahdah dianggap dianut Nestorian (lebih tepat gereja Assyria Timur yang sebenarnya tidak pernah menjadi penganut Nestorius). Padahal dalam ajaran ini, antara gereja-gereja di Timur (Yunani, Koptik, Syria, Assyria Timur) sebenarnya sama. Perbedaannya justru dengan Gereja Barat Latin dan Gereja-gereja Protestan, yang masih mempertahankan sisipan filioque dalam Kredo Nicea/Konstantinopel. 
telah turun dari surga), atau: wa kalimatuhu al-mutajjasad (dan Firman-Nya yang menjadi Manusia).43

Jadi, gelar Tuhan bagi Yesus bukan dalam makna Tuhan (ilah) selain Allah, melainkan "rabb atau Tu(h)an bagi kemuliaan Allah" (Filipi 2:11). Dalam bahasa Aram (Syria): mara hu yeshu'a mashiha le shebaha de alaha. Frase le shebaha de alaha (bandingkan dengan bahasa Arab; subhānallāh), menunjukkan bahwa melalui karya Mesiah itu ketuhanan Allah dilaksanakan, sehingga semua makhluk bertasbih memuji Allah. Jadi, gelar ketu(h)anan Yesus, sama sekali tidak menempatkan kemanusian-Nya sebagai ilah selain Allah.

Keilahian Yesus menunjuk kepada kodrat Ilahi-Nya sebagai sebagai Firman Allah, yang kekal dan bukan bersifat fisik, sebanding dengan penghayatan Islam mengenai kalām nafsiy yang qadīm dan berdiri pada Dzat Allah. Sedangkan ketu(h)anan-Nya menunjuk kepada kodrat insani-Nya, yang karena ketaatan dalam melaksanakan kehendak Allah, Yesus digelari Tu(h)an bagi kemuliaan Allah. Selanjutnya wujūd nuzūl kemanusiaan Yesus tersebut sebanding dengan penghayatan Islam mengenai kaläm lafžiy, yaitu wujud temporal kalam Allah yang nuzul dalam ruang dan waktu sebagai al-Qur'an dalam bahasa Arab (QS. Thaha:113). ${ }^{44}$

Dalam hal ini Said Aqiel Siradj menilai bahwa Gereja Ortodoks Syria tidak memiliki perbedaan yang berarti dengan Islam. Secara tawhìd alrubūbiyyah, mereka jelas mengakui bahwa Allah adalah Tuhan sekalian alam yang wajib disembah. Secara tawhīd al-ulūhiyyah ia juga telah mengikrarkan Lā ilāha illallāh; tiada tuhan (ilāh) selain Allah, sebagai ungkapan ketauhidannya. Sementara dari sisi tauhid sifat dan asma Allah secara substansial tidak jauh berbeda. Hanya ada perbedaan sedikit tentang sifat dan asma Allah tersebut. Jika dalam Islam kalam Tuhan Yang Qadim itu turun kepada manusia (melalui Muhammad) dalam bentuk al-Qur'an, maka Kristen Ortodoks Syria berpandangan bahwa kalam Tuhan turun menjelma (tajassud) dengan Ruh Kudus dan Perawan Maryam menjadi manusia. ${ }^{45}$

\footnotetext{
43 Mar Ignatius Ya'qub III, op. cit., h. 12, dalam Bambang Norsena, op. cit, h. 34.

${ }^{44}$ Bambang Noorsena, Memahami Kesalahfahaman, Beberapa Tema Teologis...., h. 32.

45 Said Aqiel Siradj, “Laa Ilaha Ilalah Juga,” dalam Bambang Noorsena, Menuju Dialog Teologis Kristen Islam, h. 165.
} 
Sementara itu sebutan Yesus sebagai "Ibnu Maryam" (Putra Maryam) yang kurang populer dalam Injil-injil kanonik, karena hanya disebut sekali dalam Markus 6: 3, justru lebih akrab jadi sebutan untuk tokoh 'Isa dalam Qur'an. Bahkan, Qur'an memberi penghormatan khusus bagi Maryam dengan kata-kata 'dan ibunya adalah seorang yang sangat benar' (QS. al-Ma'idah [5]: 75), 'Maryam yang memelihara kehormatan' (QS. al-Anbiya [21]:91, al-Tahrim [66]: 12), 'Hai Maryam, sesungguhnya Allah telah memilih engkau, mensucikan dan melebihkan engkau atas sekalian perempuan yang ada di dalam alam' (QS. Ali Imran [3]: 42). Kisah masa kecil dan peranan Maryam di kemudian hati diceritakan lebih panjang lagi dalam Surat Maryam.

Menurut Geofferey Parrinder, gelar Ibnu Maryam sangat mungkin karena pengaruh dari gereja Syria, karena hampir tujuh puluh lima persen istilah-istilah asing dalam Qur'an berasal dari bahasa Syria. Alasan ini dibuktikan oleh sebutan Ibnu Maryam yang berkali-kali disebut dalam The Gospel of Infancy dalam versi bahasa Arab dan Syria. Ini menunjukkan bahwa orang-orang kristen Syria memiliki kontak lebih erat dengan Islam mulamula. Dalam Arabic Infancy Gospel, gelar Ibnu Maryam disebut lima kali, sedangkan dalam Syriac Infancy Gospel, gelar itu muncul lima belas kali, khususnya dalam kisah kanak-kanak 'Isa. ${ }^{46}$

\section{Aspek Pola Ibadah}

Istilah șalāt dalam bahasa Arab menunjukkan doa dalam tertib dan waktu tertentu. Dalam tradisi liturgis Kristen, sejajar dengan istilah Yunani

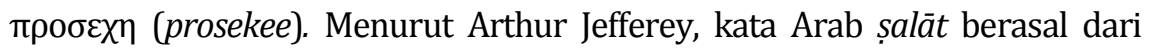
sumber Aram/Suryani/Syriac, tselota. ${ }^{47}$

Istilah tselota ini hingga sekarang dilestarikan gereja-gereja yang masih melestarikan bahasa Suryani (Gereja Ortodoks Syria, Gereja Assyria/Syria

\footnotetext{
46 Henney Sumali, "Parelisasi Kristen-Islam, Sebuah Perspektif dari Kekristenan Timur Tengah," Insitute For Syriac Christian Studies, 2002. Mengenai posisi Maryam dalam Gereja Ortodoks Syiria bisa dilihat pada, Moran Mor Ignatius Zaka I Iwas, "The Holy Virgin Mary In The Syrian Orthodox Church," SyriacOrthodox Church of Antioch, Archdiocese of The Eastern United Stated, http://www. syrianorthodoxchurch.org/ resources/library/essays/the-holy-virgin-mary-in-the-syrian-orthodox-church/.

${ }^{47}$ Arthur Jefferey, The Foreign Vocabulary of The Qur'an, Lahore: Al-Biruni, 1979, h. 197-199. Kata-kata Arab dalam Al-Qur'an yang berasal dari bahasa Suryani/ Aram/ Syriac menurutnya antara lain: Allah, șalat, 'Isa, al-masīh, al-dajjäl, subhānallāh, yang ternyata pararel dengan bentuk Suryani; Alaha, tselota,'Isha, meshiha, daggala, tehila, subh alaha. Arthur Jeffery banyak merujuk penelitiannya ini dari Al-Itqan fi 'Ulum al-Qur'an, kaya Jalal ad-Din Asy-Syuyuthi. Lihat Al-Itqān, (Dar al Fikr: Kairo, t.th.), juz I, bagian 38, dengan judul Fi mā Waqa'a fi hi bi ghairi Lughatil 'Araby.
} 
Timur, Gereja Katolik Maronit di Libanon dan Gereja Katolik Kaldea Kesatuan/Uniate Chaldean di Irak). Sedang kata Arab șalat dipakai bersamasama oleh Islam, dan seluruh gereja di Timur Tengah ${ }^{48}$, tetapi dalam hal ekpresi lahiriah ibadah (postur ruku' dan sujud) hanya Gereja Ortodoks Syria yang meneruskan ritual Yahudi dan adab timur lainnya, dimana pola ibadah yang sama juga dilestarikan oleh umat Islam. ${ }^{49}$

Bedanya, bila kaum Muslimin diwajibkan shalat 5 kali sehari, penganut Gereja Ortodoks Syria lebih banyak lagi, 7 kali sehari setiap 3 jam. Mereka menyebutnya: sa'atul awwal/saphro (fajar/Shubuh), sa'atuts tsalis/tloth sho'in (Dhuha), sa`atus sadis/sheth sho in (Zhuhur), sa'atut tis'ah tsha'sho'in (Ashar), sa'atul ghurub/ramsho (Maghrib), sa 'atun naum/sootoro (Isya'), dan sa'atul layl/ lilyo (tengah malam)..$^{50}$

Hari Gerejawi dimulai pada sore hari saat matahari tenggelam, contoh hari Senin dimulai pada saat matahari tenggelam pada Minggu sore. Oleh karena itu shalat "Maghrib" (ramsho) dan "Isya"'(sootoro) dilakukan pada hari Minggu. ${ }^{51}$

Di beberapa biara sekarang ini, shalat ini diringkas menjadi 3 kali, yaitu dengan menggabungkan antara Maghrib dan Isya', tengah malam dengan Shubuh, serta antara Dhuha, Zhuhur dan Ashar.52 Bahkan jika para penganut Ortodoks Syria ini ada kesibukan boleh dilakukan dua kali perhari, yaitu pada waktu fajar dan ketika matahari terbenam. Kalau yang ini masih juga tidak mampu, bisa dilakukan satu kali dalam seminggu, yakni pada hari Minggu. ${ }^{53}$

48 Mar Ignatius Efraim al-Awwal Bar Shauma, Patriach Antiochia dan Pemmimpin Tertinggi Gereja Ortodoks Syria (1887-1957), menyusun buku mengenai shalat tujuh waktu yang dilakukan oleh para pengikut gereja ini dalam dua bahasa Suryani dan Arab dengan judul; al-Tuhfat al-Ruhiyat fi I-Ṣalat al-Fardhiyah. Lebih jauh tentang karya-karyanya, bisa dilihat pada pengantar penterjemah dari bukunya, Kitāb al-Lulu al-Manțūr fi Tarīkh al-Ulūm wa 'l-Adab al-Suryaniyya Lihat, Ignatius Aphram I Barsoum, The Scattered Pearls, terj. Matti Moosa, Gorgias Press: Piscataway NJ, 2003.

${ }^{49}$ Bambang Noorsena, op. cit., h. 10-12. Oleh karena itu Gereja-gereja Ortodoks Timur percaya bahwa bila dibandingkan dengan Gereja Roma Katolik merekalah yang paling asli. Lihat Mical Keene, Kristianitas, terj. FA. Soeprapto, (Yogyakarta: Kanisius, 2006, h. 66.

50 Mengetahui Ortodoks Syria, http://gereja.phpbb24.com/viewtopic.php?t=295, diakses tanggal 27 November 2007. lihat juga, "Worship in the Syriac Orthodox Church," Syriac Orthodox Resources, http://sor.cua.edu/Worship/index.html, diakses tanggal 27 November 2007.

${ }^{51}$ St. Thomas Syriac Orthodox Church, http://stsyriacchurch.homeip.net/history. htm, diakses tanggal 27 November 2007.

52 "Worship in the Syriac Orthodox Church," Syriac Orthodox Resources, loc. cit.

53 HMO, Mauluddin Anwar, dan A. Murtafie Haris, "Ada Jilbab, Khitan, dan Jenggot", http://groups. google.co.id/group/soc.culture.Indonesia/msg/687942098847798, diakses pada tanggal 27 November 2007. 
Tidak hanya itu persamaan dengan Islam. Tenyata mereka juga mengenal haji. Ibadah haji ke Palestina ini termasuk ibadah non-sakramen, seperti juga shalat, zakat persepuluhan, serta puasa. Berdasar Kitab Ulangan 16: 16-17 disebutkan hag atau haji dilakukan ke tanah suci Palestina menjelang Pekan Kudus (perayaan Paskah). tiga kali dalam setahun. Dan sepulangnya, setiap orang Kristen Ortodoks mendapatkan sertifikat dari Patriakh Jerusalem dengan sebutan hadhi (untuk pria) dan hadhina (untuk wanita)..$^{54}$

Puasa wajib bagi pemeluk Islam yang dilakukan selama sebulan dalam setahun, dikenal dengan șaumu Ramaḍān. Sedang pada Gereja Ortodoks Syria disebut șaum al-kabïr (puasa 40 hari berturut-turut) yang dilakukan menjelang Paskah sekitar bulan April. Jika dalam Islam ada puasa sunnah SeninKamis, pada Gereja Ortodoks Syria dilakukan pada Rabu-Jum'at, dalam rangka mengenang kesengsaraan Kristus. ${ }^{55}$

Selain puasa tersebut, umat Ortodoks Syria umat Ortodoks Syria juga berpuasa 40 hari menjelang Idul Milad (Natal), kemudian puasa 50 hari lagi setelah Hari Pentakosta. Masih ditambah tiga hari puasa Niniwe yang dimulai dari hari Senin, seminggu sebelum peringatan Paskah dan puasa 15 hari di bulan Agustus yang disebut șaum Maryam al-Adzrā’i (Puasa Maria Sang Perawan). Puasa sepanjang tahun dilakukan pula setiap hari Rabu dan Jumat, sesuai dengan ajaran Didache. Kemudian, dilakukan puasa tiga hari setiap ada hari-hari suci untuk mengenang para martir.

Dalam Gereja Ortodoks Syria, puasa adalah tindakan sukarela untuk melepaskan kehidupan duniawi. Puasa dilakukan dengan meninggalkan makanan atau minuman dalam periode waktu tertentu, dan berakhir dengan memakan sedikit makanan, sepotong daging kecil yang tidak berlemak, makanan yang terbuat dari biji-bijian, kacang-kacangan, dan minyak nabati. Orang yang puasa menahan diri dari memakan daging dan produk-produk dari binatang kecuali ikan dan seluruh hasil laut, serta madu. Puasa diperintahkan bagi orang yang beriman, dewasa dan sehat. Orang-orang tua,

54 M.H., Titi A.S., dan Abdul Manan, Gereja dengan Haji dan Sholat, http:// jurnalis. wordpress.com/1998/10/03/gereja-dengan-haji-dan-shalat/, diakses tanggal 27 November 2007. Gambar postur-postur ibadah Yahudi yang dilestarikan gereja purba dan juga umat Islam bisa dilihat di The Unger Bible Dictionary, diedit oleh R. K. Harrison, Moody Press, 1988.

55 Mengetahui Ortodoks Syria. 
anak-anak, bayi, orang sakit, perawat, wanita yang habis melahirkan, atau mengandung, dikecualikan. ${ }^{56}$

\section{Gereja Ortodoks Syria dalam Hubungan Islam - Kristen}

Semenjak awal, Islam memandang dirinya sebagai ungkapan keimanan dan ketundukan (islām) Ibrahim ${ }^{57}$ kepada Allah. Lebih dari itu, keimanan ini tidak hanya terbatas pada Nabi Ibrahim tetapi juga dimiliki oleh semua nabi sebelum dan sesudah Nabi Ibrahim, termasuk Nabi Musa dan Isa. Islam pada masa Nabi Muhammad dan para sahabat dekatnya tidak menuntut para ahli kitab untuk meninggalkan agama mereka sebagai biaya hidup atas persahabatan dan interaksi yang baik dengan kaum Muslim.

Sekalipun, sebelum Islam lahir sebagai "agama," Arabia memang dikelilingi oleh pengaruh agama Kristen, ${ }^{58}$ (bahkan sebagian besar orang Kristen Mekkah, dan Yaman adalah pengikut Gereja Ortodoks Syria), ${ }^{59}$ namun hati dan kehidupan rakyat Arabia ternyata belum terjamah oleh kekristenan. Pemikiran-pemikiran, ajaran-ajaran dan kesenian Kristen memang telah cukup lama mengitari dan mempengaruhi daerah Arabia, tetapi kekristenan belum menyentuh kehidupan dan kebutuhan yang amat mendasar dari rakyat Arabia. Disamping itu, di dalam agama Kristen di Arabia telah terjadi perpecahan satu aliran terhadap aliran lainnya dan sangat mengedepankan sikap yang saling bermusuhan. ${ }^{60}$ Kekristenan belum menjadi semacam "payung besar" yang meletakkan rakyat di dalam kesejajaran yang nyaman. Sehingga tidak mengherankan ketika sebagian besar umat Kristen di Timur Tengah kemudian berpindah ke dalam agama Islam.

56 Moran Mor Ignatius Zakka I Iwas, "Fasting, Essays on Syriac Theology \& Spirituality," Syriac Orthodox Church of Antioch, Archdiocese of The Eastern United Stated, http://www. syrianorthodoxchurch.org/resources/library/essays/, diakses tanggal 28 Juli 2009.

57Dari Ibrahimlah kemudian dikenal konsep "Tuhan Ibrahim" (Elohe Avraham) yang kemudian diwariskan turun-temurun kepada anak cucunya.Lihat, H.H. Rowley, Ibadat Israel Kuno, terj. I.J. Cairns, (Jakarta: BPK Gunung Mulia, 2002), h. 9.

${ }^{58}$ R. Bell, The Origin of Islam In Its Christian Environment, (Edinburg: T\&T Clark, 1968), p. 41.

${ }^{59}$ Maren Tyedmers Hange, (ed)., "A Short Overview of the Common History of the Syrian Church with Islam through the Centuries". Patriarchal Journal Vol. 33, No. 146, Juni 1995, h. 322-344. Lebih jauh menurut Th. Van De End, karena banyak orang Kristen Syria telah menetap di Arabia Barat laut (beberapa suku Arab misalnya Bani Ghassan, telah masuk Kristen) dan karena banyak biara Syria dibangun di padang pasir Arabia Utara, barangkali bentuk agama Kristen inilah yang dikenal Nabi Muhammad. Lihat, Th. Van Den End, Christian de Jonge, Sejarah Perjumpaan Gereja dan Islam, (Jakarta: BPK Gunug Mulia), h. 14.

${ }^{60}$ R. Bell, The Origin of Islam In Its Christian Environment, pp. 43-46. 
Oleh karena itu orang Kristen Suriah menaruh harapan besar pada kaum Muslim, tidak hanya karena orang Islam membebaskan mereka dari gangguan terhadap keyakinannya,61 tetapi juga karena umat Islam membebaskan orang Suriah dari pajak yang membebani mereka. Sehingga mereka menafsirkan bahwa gelar al-Faruq, yang diberikan kepada Khalifah Umar adalah berasal dari bahasa Syria, "Faruqo" yang berarti juru selamat. Gelar ini diberikan kepada Yesus Kristus dan kemudian kepada Kalifah Umar. Selanjutnya mereka berkata: "Puji Tuhan, yang membawa kita dari ketidakadilan orang Byzantium dan menaruh kita di bawah kekuasaan orang Islam Arab."62

Namun hubungan yang harmonis tersebut terkadang juga mengalami hambatan ketika Syria dikuasai para penguasa Turki, namun hubungan baik ini sekarang sudah terjalin kembali, dengan kembalinya pusat Gereja Ortodoks Syria ini di Damaskus, Syria.

Di Indonesia, karena gereja ini termasuk "pendatang baru," maka memang belum banyak memberi pengaruh besar dalam hubungan IslamKristen. Namun berbagai bentuk forum dialog telah dirintis seperti Forum Dialog Teologis, bekerja sama dengan Yayasan Paramadina di Hotel Sahid Jakarta, serta ikut dalam berbagai bentuk kegiatan lintas agama di berbagai Kota di Indonesia.

\section{E. Kesimpulan}

Meskipun dalam ajaran ketuhanan, Gereja Ortodoks Syria tidak bisa dikatakan menganut ajaran monoteisme murni sebagaimana Islam, namun masih banyak bisa diketemukan paralelisasi dengan Islam dalam aspek teologis yang lain, dan terutama dalam hal pola ibadah. Pemahaman yang mendasar serta mendalam dalam hubungan Islam-Kristen serta suasana sharing of religious experience, akan membentuk sikap keberagamaan yang lapang dan tasamuh dapat dikembangkan dalam masyarakat yang plural seperti Indonesia ini, khususnya melalui dialog antar agama.[w]

\footnotetext{
61 Gereja Katolik dan Ortodoks Timur menganggap Gereja Ortodoks Syria menyimpang dari faham agama sebenarnya. Lihat, Ag. Pringgodigdo, Ensiklopedi Umum, (Yogyakarta: Kanisius, 1991), h. 368.

62 Maren Tyedmers Hange, (ed)., "A Short Overview of the Common History of the Syrian Church with Islam through the Centuries," Patriarchal Journal, Vol. 33, No. 146, Juny 1995, pp. 322344.
} 


\section{BIBLIOGRAFI}

Barsoum, Ignatius Aphram I, The Scattered Pearls, terj. Matti Moosa, Piscataway NJ: Gorgias Press, 2003.

Bell, R., The Origin of Islam In Its Christian Environment, Edinburg: T\&T Clark, 1968.

De Jonge, Th. Van Christian Sejarah Perjumpaan Gereja dan Islam, Jakarta: BPK Gunug Mulia.

Dister, Nico Syukur, Kristologi, Sebuah Sketsa, Yogyakarta: Kanisius, 1993.

Enklaar, I. H., Sedjarah Gereja Ringkas, Jakarta: Badan Penerbit Kristen, 1955.

Gani, Fathudin Abdul, “Agama Katolik," dalam Djam'annuri (ed), Agama-agama di Dunia, Yogyakarta: IAIN Sunan Kalijaga Press,1988.

Hange, Maren Tyedmers (ed)., "A Short Overview of the Common History of the Syrian Church with Islam through the Centuries," Patriarchal Journal, Vol. 33, No. 146, Juni 1995.

http://en.wikipedia.org/wiki/Patriarch_of_Antioch, diakses pada tanggal 3 September 2009.

http://en.wikipedia.org/wiki/Syriac_Orthodox_Church, diakses tanggal 29 November 2007.

http://gereja.phpbb24.com/viewtopic.php?t=295, diakses pada tanggal 27 November 2007.

http://Groups.google.co.id/group/soc.culture.Indonesia/msg/68794209884779 8, diakses pada tanggal 27 November 2007.

http://i.cios.com/e.o/syr.orth.htm., diakses pada tanggal 27 Desember 2007.

http://id.wikipedia.org.wiki.Denominasi_Kristen, diakses tanggal 7 Mei 2007.

http://id.wikipedia.org/wiki/Filioque, diakses tanggal 2 Januari 2008.

http://id.wikipedia.org/wiki/Gereja-Ortodoks-Oriental, diakses tanggal 29 April 2007.

http://id.wikipedia.org/wiki/Keduabelas_Rasul, diakses pada tanggal 2 Januari 2008.

Walisongo, Volume 20, Nomor 1, Mei 2012 
http://id.wikipedia.org/wiki/Miafisitisme, diakses pada tanggal 27 Desember 2007.

http://jurnalis.wordpress.com/1998/10/03/gereja-dengan-haji-dan-sholat/, diakses pada tanggal 27 November 2007.

http://sor.cua.edu/History/index.html, diakses tanggal 26 November 2007.

http://sor.cua.edu/Intro/index.html, diakses tanggal 22 Desember 2007.

http://sor.cua.edu/Worship/index.html, diakses tanggal 27 November 2007.

http://stsyriacchurch.homeip.net/history.htm, diakses pada tanggal 27 November 2007.

http://stsyriacchurch.homeip.net/history.htm, diakses pada tanggal 27 November 2007.

http://www.angelfire.com/journal2/iscs/faq.htm, diakses pada tanggal 27 Desember 2007.

http://www.encyclopedia.com/doc/1095-SyrianOrthodoxChurch.html, diakses pada tanggal10 Juni 2009.

http://www.goina.org/?uPos=L\&uMenu=10\&uSys=19\&uCaption=Sejarah\%20G ereja, diakses pada tanggal 27 Desember 2007.

http://www.syrianorthodoxchurch.net/Location/Global/SOC-index-Globalen.htm, diakses pada tanggal 27 November 2007.

http://www.syrianorthodoxchurch.org/resources/library/essays/, diakses pada tanggal 28 Juli 2009.

http://www.syrianorthodoxchurch.org/resources/library/essays/the-holyvirgin-mary-in-the-syrian-orthodox-church/.

Jefferey, Arthur, The Foreign Vocabulary of the Qur'an, Lahore: Al Biruni, 1979.

Jeffery, Arthur, The Foreign Vocabulary of the Qur'an, Lahore: Al-Biruni, 1977.

Keene, Mical, Kristianitas, terj. F.A. Soeprapto, Yogyakarta: Kanisius, 2006.

Lembaga Al-Kitab Indonesia, Perjanjian Baru, Kisah Para Rasul, Jakarta,1993

Lambertus L. Hurek, Gereja Ortodoks Syria di Indonesia, http://hurek.blogspot. com/2005/12/gereja.ortodoks.syria.di.Indonesia.html., diakses tanggal 27 Desember 2007.

Mahmoud M. Ayaoub, Mengurai Konflik Muslim - Kristen dalam Perspektif Islam, terj. Ali Noer Zaman, Yogyakarta: Fajar Pustaka Baru, 2001. 
Maren Tyedmers Hange, (ed.)., "A Short Overview of the Common History of the Syrian Church with Islam through the Centuries". Patriarchal Journal Vol. 33, No. 146, Juni 1995.

Mingana, Alphonsus, "Syrian Influence on the Style of the Kur'an," Bulletin of the John Rylands Library, Manchester 11, (1927).

Mu'in, Taib Thahir Abdul, Ilmu Kalam, Jakarta: Widjaya, 1986.

Noorsena, Bambang, Menuju Dialog Teologis Kristen Islam, Yogyakarta: Yayasan Andi, 2001.

- Memahami Kesalahfahaman, Beberapa tema Teologis dalam Perjumpaan Kristen-Islam, Denpasar: Bali Jagadhita Press, 2002.

Pringgodigdo, Ag., Ensiklopedi Umum, Yogyakarta: Kanisius, 1991.

Rowley, H.H., Ibadat Israel Kuno, terj. I.J. Cairns, Jakarta: BPK Gunung Mulia, 2002.

Sah, Idries, Meraba Gajah dalam Gelap: Sebuah Upaya Dialog Kristen-Islam, Jakarta: Grafiti Press, 1986.

Titi A.S., M.H., dan Abdul Manan Surabaya, D\&R, Edisi 981003-007/hlm 38 Rubrik Agama, Gereja dengan Haji dan Salat, http://jurnalis. wordpress. com/1998/10/03/gereja-dengan-haji-dan-salat/, diakses tanggal 26 Nupember 2007.

Trimingham, J. Spencer, Christianity among The Arabs in Pre-Islamic Times, London: Longman Group Ltd., 1979. 
